\title{
Application of a Visual Simulation System for Revegetation by Plant Modeling
}

\author{
Morimoto, Yukihiro*
}

\section{1. はじめに}

近年, 緑化の目的の多様化や緑化技術の発展にともな い, 施工前に緑化景観を予測することの必要性が増して きている。特に景観保全や生活環境保全を目的とする場 合には, 良好な緑化景観の形成が重要な目的であるから, 緑化の計画や設計段階において, 緑化景観を予測し, 検 討することが必須である。しかし多くの場合, どんな緑 化景観が創出されるか, という問題は計画・設計者の経 験に頼っているのが実情である。また, 景観そのものが 特に問題とならないような場合でも, クライアントや第 3 者との合意形成のために評価用の品質の高い予想図が 出力できれば大変有用であろう。

このような目的のための手段は, 従来は手書きのパー スが主流であったが, 近年コンピュータ・グラフィック スの利用も見られるようになってきた。本稿では現在, 植物の 3 次元形状をモデリングした, 最も進んだ景観表 示ソフトウェアと思われる AMAP を紹介し, 緑化景観 予測への利用について論じたい。

\section{CG と緑化景観予測}

コンピュータグラフィックスで緑化景観をシミュレー ションするといっても, それにはさまざまな方法が考え られる。また, 現在まで, さまざまな方法が試みられて きたが，パソコンレベルでテレビ画像程度のカラー情報 が取り扱えるようになってから，急速に実用的な利用上 の進歩が見られるようになってきたといえる。かつては

\footnotetext{
* 京都造形芸術大学環境デザイン研究室 Kyoto Univ. of Art \& Design
}

プロッ夕を用いて線画の出力も行われたが, 現在ではふ つう, なんらかのカラー画像が成果品とされるようにな った。

緑化景観のシミュレーションの課題はいろいろある が, CG一般に共通の課題以外の, 独自の課題としてはつ ぎの 3 点が重要だろう。

まず，第 1 点は植物の形態の植物学的なリアリティに 関する情報をどのように持つかということである。ふつ う, 2 次元の画像データの場合と 3 次元のデータの場合 がある。2 次元画像の場合は写真やビデオによる実写画 像によるか, ペイントまたはドローによって CG で作成 される。前者の場合は比較的簡単にリアリティの高い画 像が得られるが, 視点を自由に移動させることはできな い。一方， 3 次元データの場合はふつうポリゴンとして モデリングされるが, 植物の形態が複雑なためデータ量 が膨大となりやすく，モデリングおよびレンダリングの 方法によっては時間がかかる。

第 2 点は, 計画・設計やシミュレーション目的にいか に実用的なツール類が準備できるか, という点である。 緑化に関する画像データの収集, 加工, 切り貼り, 重ね 合わせ, アニメーション, 画像出力, データベース化, $\mathrm{CAD}$ との連動など, 実用化にむけて課題は多い。

第 3 点は, 植物の成長と枯死によって変化していく植 物景観をいかにシミュレーションするか, ということで ある。これは一見, 計画・設計段階の CAD とは関係ない とも言えるが, 緑化工が生きた植物をとり扱っている以 上, 生態学的にありえない景観をリアルに表現しても意 味が少ないからである。理想的には生態学的な諸条件に 対応した将来予測ができて, はじめて植物景観のシミュ レーションが完成したというべきだろう。緑化工事終了 
時点は真の緑化景観の完成時点とは言い難いのである。 これらをすべて一定程度満足させるシステムは今のと ころまだない。しかし, 限定された目的のためには研究 および実用化が進んできた。たとえば切り貼りによる 2 次元画像処理でも, パソコンレベルでもいわゆるフルカ ラー $\left(2^{24}\right.$ 色 $)$ で大画面が普通に扱えるようになり, 優秀 なペイント・レタッチ用プログラム (Photoshop, Super Tableauなど）で，かなり実用的な画像を出力できる。 手前のものを取り除いた景観のシミュレーションも， 2 次元のシステムでは厳密には不可能だが，奥に位置する 物が見える視点からの画像を変形させて合成するなど, スキルによってある程度欠点をカバーできる。ただし， そのリアルさはオペレータの熟練にかかっている。その 点はちょうど手書きパースの表現のリアルさが描き手の 技巧にかかっているのと同様である。

一方, 従来の 3 次元のデータを取り扱う $\mathrm{CAD}$ システ ムでは, 正確なパースペクティブは簡単に描けるものの, 複雑な植物の形状をそのまま取り扱うことが困難であ り，簡略化の度合が大きいために，リアルさに欠けるこ とが多かった。リアルさはデータの量そのものやレンダ リング手法による, いわば CG の一般的技術に負う部分 と，植物らしい形態とその成長の数理的表現，つまりモ デリング技術による部分がある。両者の進歩によって初 めて実用的なシステムが成立する。通常の物質の CG 表 現と異なって, 特に植物の形態は成長によって変化する ことが特殊な点であるが, 成長エンジンを備えたモデリ ングが行われるに至った。これによって，植物の成長に ともなう景観の変化などのシミュレーションがスマート に行えるようになったといえる。

\section{3. 植物モデリング}

植物をパース表示プログラムで扱うにはなんらかの 3 次元構造をモデリングしなくてはならない。単に植物が 添景として用いられる建築物主体のプログラムでは, 何 となく植物らしければよいということで, 円柱の幹に回 転楕円体をつけたり, あるいは円柱や円錐の幹に数枚の 透明な板を地面に垂直に立て, 葉らしい模様をマッピン グするようなことも行われてきた。

一方, 植物の全体形状の法則性に関する研究はかなり 前から行われており, フラクタル的分枝構造であるホー トンの法則の樹木への適応性に関する研究をはじめ, 分 枝構造の数学的モデルや生物学的モデルがいくつか発表 されている。この点に関しては本條ら゙3がこれまでの状 況をとりまとめている。これらの研究成果を緑化景観シ ミュレーションに実用的に使うためには一般的な樹形の
モデリング理論だけでなく, 多様な樹種のデータ, それ らのリアリティの高いレンダリング技術, 使いやすいユ ーザーインターフェイスなどが必要である。

これらの意味で，いままで開発されたプログラムのな かで, 汎用的に利用できそうなものは多くない。植物の 3 次元構造を生成する実用的なソフトウェアは, おそら く,ひとつは日本で開発された GDS であり,もうひとつ はフランスで開発された AMAPであろう。

\section{AMAP}

4.1 ハードウェアとソフトウェア

フランスのCIRAD (Centre de Cooperation Internationale de Recherche Agronomique pour le Developpement) で開発されたAMAP (Atlier de Modelisation pour l'Architecture des Plants) は実際 の植物の形態と成長過程の研究に基づいた，植物景観の CG プログラムに大きな特徴がある。植物の成長にとも なう形態の形成に関しては古くからアフリカ象牙海岸の 研究所でコーヒーやオイルパームを対象に研究が行われ ていた実績がある。CIRAD の植物モデリング研究室を 中心として, 多数の植物, 農学, コンピュータの専門家 の共同研究として AMAP が開発された。現在, AMAP の植物モデルには 3 種類ある ${ }^{4)}$ 。現在, 市販されているの はアーキテクチュラル・モデルであり,これよりもかん たんな初歩的モデルと逆に生物学的意味を追及したバイ オロジカル・モデルがある。最初, フランスで用いられ る種類しか市販されていなかったが, 北米および日本の 樹種もライブラリに加えられた。

このソフトウエアはグラフィックワークステーション であるシリコン・グラフィックス社の IRIS4D シリーズ 上で走り, 以下のようなソフトウェアのモジュールから 成っている。

・ACCESS : CAD/CAM データのフォーマット変換ツ ールで,一般的に用いられているDXFファイルを AMAP 内で用いるARCHITECT などのファイルに変 換する。

・VISU (GLANCE)：植物の成長エンジンを備えてお り，パラメータ・ファイルから形状をモデリングして高 速にビジュアライズする対話型ツールで，これが最もュ ニークな部分といえる。これで生成した植物を RGBIM で用いたり，ポリゴンデータとして exportし, AMAP 以外の CG プログラムのデータとして用いることができ る。

-RGBIM (LANDMAKER) : 対話的に植物, 建築物, 地 形を組み合わせて景観を構築するツールで, 日影や霧の 
効果も含めたレンダリング, アニメーションもサポート している。

・CALRGB : RGBIM のバッチ処理ツール。

-MAPRGB： 3 次元オブジェクトのマテリアル特性の チェックと修正ツールで, shinness および, 3 原色の特 性として, ambient, diffusion, emission, specular 定義する。

•GENSURF : 地形モデラで, RGBIM で使用するデー 夕を作成するツールである。制御点の最大数は現在のバ ージョンでは 8000 点であるが, 25000点に増やす予定とい う。もちろん別に作成した地形データも読み込める。標 高に応じて MAPRGB で特性を定義し, RGBIM でのレ ンダリングにおける色と形の補間のレベル, すなわち画 像の品質は 4 段階あって選択できる。

-SYMB : 植物の各部分の 3 次元形状のモデラであり, ポリゴンとその法線べクトルを定義できる。

4.2 AMAP の特徵と利用

\section{2 .1 樹種の選択}

乱数を用いて樹形の個体変異のシミュレーションがで きる。実際にはランダム・シードを適宜与えることによ って, その樹種の樹形がどの程度変動するかを検討でき る。これは通常の植栽のための図鑑類では困難なことで ある。

AMAP がデータを持っていない場合, 変種や形態的 に類似の種なら, SYMB で修正して用いることができ る。

\section{2 .2 成長の予測}

成長エンジンを用いて成長に伴う形態の変化をシミュ レーションできる。ただし，これは個別具体的な植栽環 境に対応しているわけではなく, 統計的に得られた平均 的な形状の変化を示している。レンダリングの品質も精 度と速度の必要に応じて変えられる。品質を上げた場合, 数十年生の樹木のようにポリゴン数が多くなると反応が 遅くなるが, 一応, リアルタイムに 3 次元シェーディン グ表示で検討できる。また，種子番号をランダムシード として与えることで, 個体変異の程度も検討でき.る。

\section{2 .3 景観の構築とシミュレーション}

GENSURF は対話的に形状を確認しながらマウス操 作で高さの制御点を設定するユニークなモデラーであ る。また RGBIM は植物だけでなく, 地形や構造物が取 り扱えるが, モデリングされた植物や建築物を地形の上 にソートする機能を持っている。これは大変実用的な景 観構築用ツールである。地形をシェーディングして表示 できるが, その際, 明るさと色を指定できる。レンダリ ングの品質は 4 段階で, 速度を考慮して選択する。滑ら
かな地形のモデリングに優れている。 アニメーションの基本機能では視点と注視点の始点と 終点, およびその経路, 移動速度制御を対話的に設定で きる。滑らかなウォーク・スルーのシミュレーションに 適している。

このような特徴から, 景観設計の特に構想・企画段階 において, 土地の形状をいろいろ変えて, さまざまなケ ースの景観をチェックしたいときに役立つだろう。

RGBIM や CALRGB のレンダリングはたいへん高速 である。品質はレイトレーシングには劣るが，1本あた り数十万ポリゴンという膨大なデー夕量の樹木が充分な リアリティを発揮する。しかも 1 本あたりせいぜい数秒 しかかからないので, 多数の植物がある場合でも高品質 の画像で試行錯誤しながら景観を検討できる利点があ る。

\section{AMAP 使用事例}

\section{1 ベニバナトチノキの樹形の検討}

植物成長エンジンの使用事例を図 1 に示す。これは VISU で作成した樹木を視点を変えて，実体視できるよ うに配置したものである。樹齢 3 年, 10 年, 10 年（別の 種子), 15 年, 20 年, 27 年である。

\section{2 内蒙古毛烏素砂漠}

中国内蒙古の毛鳥素砂漠ではヤナギ類の挿し木による 緑化が行われている。筆者らも, 当地の研究センター東 試験地にモデル砂丘を設定し, 形状や植生の変化を調査 している5)。そこに, ヤナギ類で緑化した場合の景観をシ ミュレーションした。(図 2)

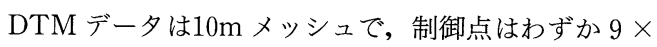
10点である。

\section{3 糺の森}

糺の森は京都市の賀茂川と高野川合流点付近に成立す る下鴨神社の宮の森であり, 都市緑地として極めて重要 な意味をもち, 史跡に指定されている。もともとニレ科 樹種を主体とする河畔林であったが, 昭和 9 年の室戸台 風による被害後に植えられた非郷土樹種のクスノキが近 年増加してきている ${ }^{6)}$ 。この状況をビジュアルに観察す るために1991年に行った直径 $10 \mathrm{~cm}$ 以上の樹木に関する 毎木調査データ7)を用いて AMAPを用いた景観シミュ レーションを行った。

まず,ここで出現する樹種ないし, それに類似した種 のオブジェクト・データをVISU で作成した。つぎに樹 木の位置, 樹種, 大きさのデータがあるので, 変換プロ グラムを作成して AMAP のシーン・ファイルにした。 なお, AMAP のシーン・ファイルは視点, 注視点, ウ 


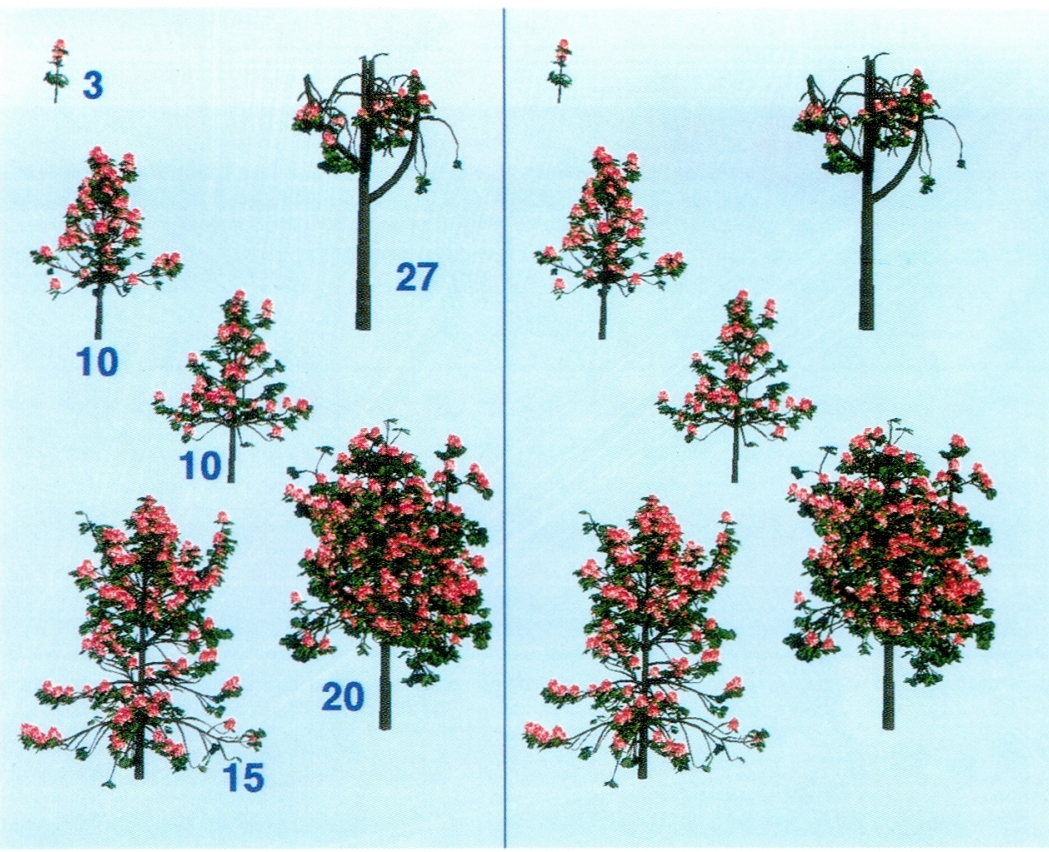

図 1 AMAP を用いたトチノキの 1 種の実体視画像の生成（数字は樹令）

Fig. 1 Stereoscopic images of Aesculus sp. by AMAP (each numeral means age.)

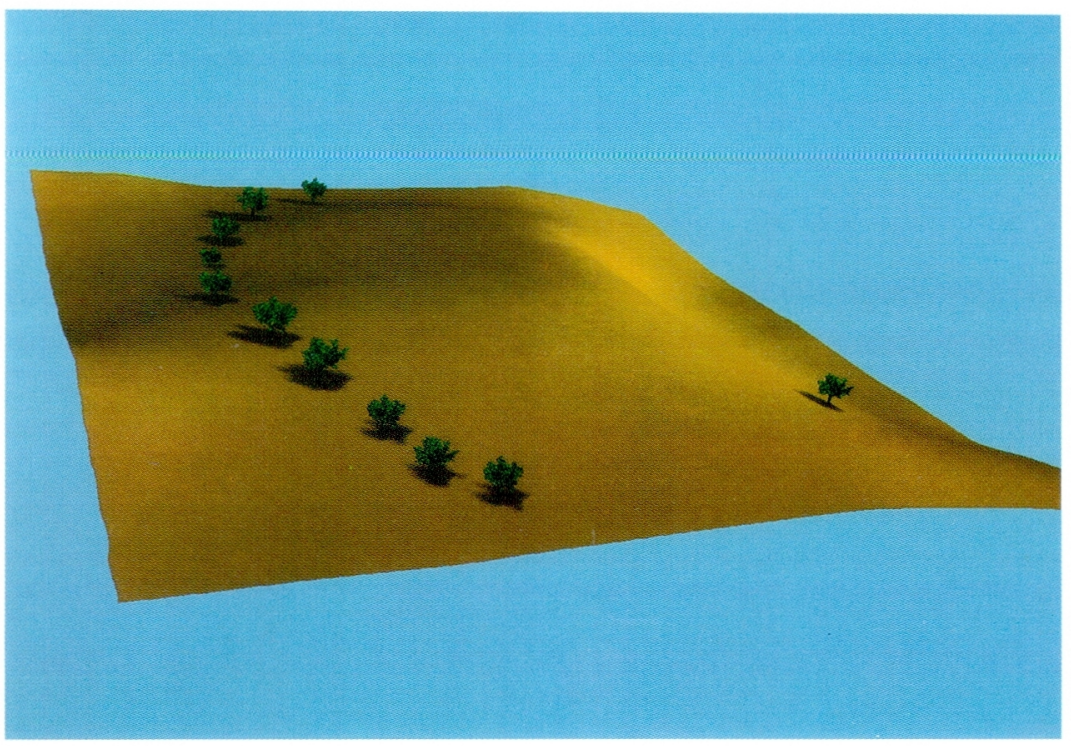

図 2 中国内蒙古毛烏素砂漠の砂丘とヤナギ類による緑化景観シミュレーション

Fig. 2 Visual simulation of sand dune and planting of Salix sp. in Mu-Us desert, China 


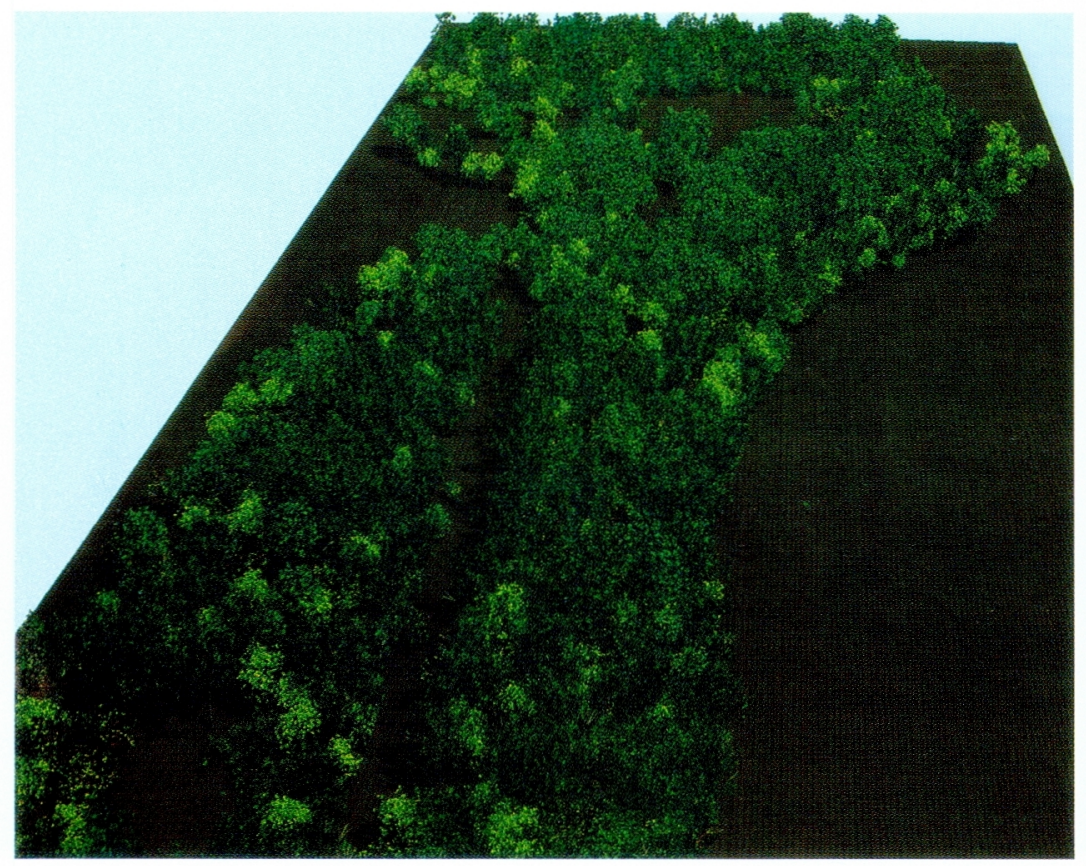

図 4 京都下鴨神社, 糺の森の毎木調査結果の可視化

Fig. 4 Visualization of the results of the tree survey in Tadasu forest in Kyoto

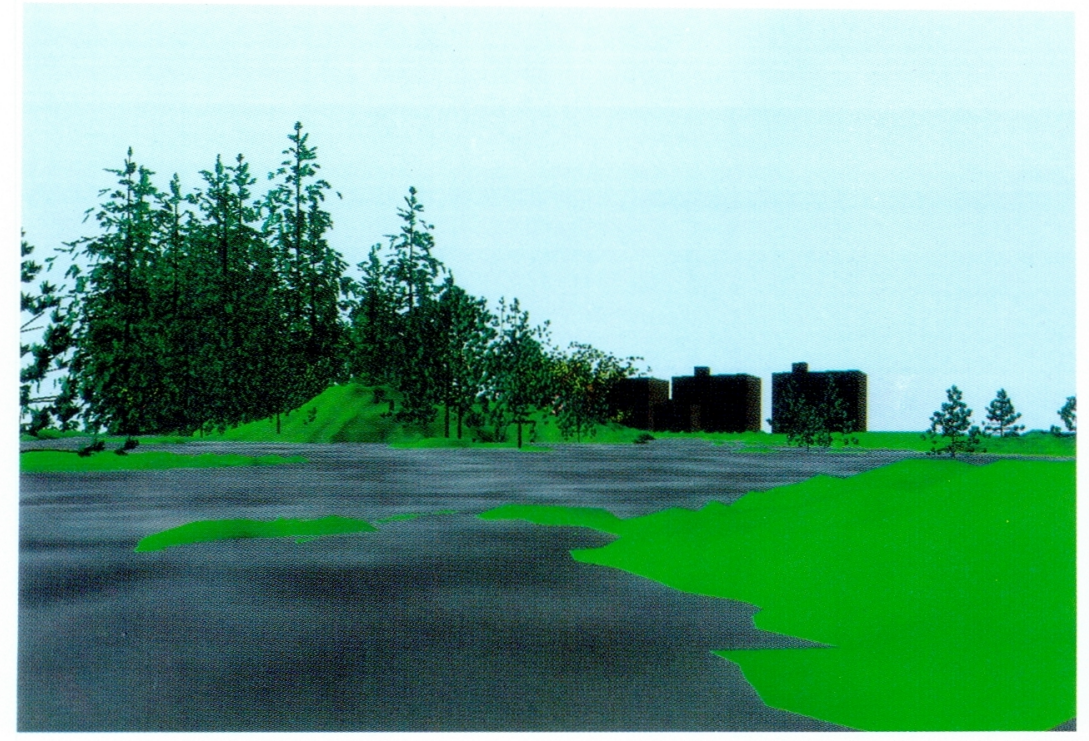

図 5 仮想建築物の桂離宮庭園景観への影響の検討

Fig. 5 A visual impact study of possible buildings on the Katsura imperial garden 
図 3 AMAP シーン・ファイルにおける地形と植物の 記載例

Fig. 3 Example of the discription of a terrain and a plant in the scene file

\begin{tabular}{|c|c|c|}
\hline Element & & （地形エレメント） \\
\hline Numero & 11 Fin & 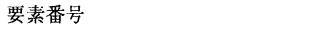 \\
\hline \multicolumn{3}{|c|}{ Global } \\
\hline Objet & 10 & オブジェクト番号 \\
\hline Nature & 5 & 要素タイプ（5:地形） \\
\hline Detail & 4 & レンダリングのレベル \\
\hline Visible & 1 & 表示／非表示 \\
\hline Terrain & 1 & 地形の上にソート／非ソート \\
\hline Nom & dune & オブジェクト・ファイル名（dune） \\
\hline \multicolumn{3}{|r|}{$x^{2}$} \\
\hline \multicolumn{3}{|c|}{ Geometrie } \\
\hline Echelle & 0.1001 & 縮尺 \\
\hline Angle & 0.0000 & 回転角度 \\
\hline Incline & 0.0000 & 傾き角度 \\
\hline Position & $-3.03260 .0000-11.0446$ & 位置 \\
\hline \multicolumn{3}{|c|}{ Fin } \\
\hline Element & & （植物エレメント） \\
\hline Numero & $12 \mathrm{Fin}$ & \\
\hline \multicolumn{3}{|c|}{ Global } \\
\hline Objet & 11 & \\
\hline Nature & 1 & 要素タイプ (1:植物) \\
\hline Detail & 4 & \\
\hline Visible & 1 & \\
\hline Terrain & 1 & \\
\hline Nom & pinus_b03021 & (マツb、種子No. 3、21年生) \\
\hline Fin & & \\
\hline \multicolumn{3}{|l|}{ Geometrie } \\
\hline Echelle & 0.0004 & \\
\hline Angle & 12.8571 & \\
\hline Incline & 0.0000 & \\
\hline $\begin{array}{l}\text { Position } \\
\text { Fin }\end{array}$ & $\begin{array}{llll}5.3262 & 0.4839 & -5.4904\end{array}$ & \\
\hline
\end{tabular}

インドウ, ビューポート, 解像度, 前後のクリッピング などのパース情報と光源の情報に加えて, 地形や樹木, ポリゴン, 建築物などのオブジェクトの名称と位置, ス ケール, 傾きなどの, そのシーンでの情報で構成される。 シーン・ファイルでの地形と植物エレメントの記載例を 図 3 に示した。

地形はほとんど平坦であるため,あまり意味はないが， $10 \mathrm{~m}$ メッシュのDTM とした。なお,これは $1 / 2,5000$ 都 市計画基本図をパソコン（pc9801vm4とタブレット・デ ジタイザ）で等高線をランダムに読み取り，距離の 2 乗 分の 1 の重み付けでリサンプリングしている。この DTM を GENSURF でAMAP のデータに変換し, 適当 な色情報を付加して用いた。

レンダリング例を図 4 に示す。樹木は全部で3449本あ りこのレンダリングに要した時間は約20分であった。 これによって,クスノキがほぼ全域に分布していること, 落葉広葉樹林は, すでにかなり限定された範囲になって いることなどが視覚的に明瞭にとらえられた。

\section{4 桂離宮庭園}

現在, 桂離宮庭園の情報化については別途研究中であ
るが, 図 5 は付近に建設中の国道バイパスの完成にとも なう建築物高さ規則変更があった際に建築物による庭園 景観破壊がおこるかどうかを検討した際の中間生成画像 である。主要視点場からの見えかたを, 庭園建築物や樹 木を一部省略してレンダリングしてある。

\section{6. 今後の課題}

AMAP の植物ライブラリには日本で使われる種が少 ないので, 日本の樹種のライブラリが作成されるまでは, 類似の種を用いたり，修正して使用する必要がある。ま た植物は原則的に自然樹形である。生け垣風に刈り込ん だ樹種はあるが，日本の庭園などで行われる剪定された 樹形のサポートが早急に望まれる。

つぎに, VISU の成長エンジンは一般的な成長環境を 想定しているが，かならずしも具体的な場所に対応しな い可能性もある。植物の形態は遺伝情報と環境の関係で 決まるものだからである。すでに，2 個体の相互作用を 考慮したパラレル成長と, 剪定とその後の萌芽成長の基 本的なアルゴリズムは開発されているが4), 立地条件と 群落的環境を考慮した成長エンジンの開発は今後の非常 に重要なテーマとなろう。

\section{文献}

1) Honda, H. : Description of the Form of Trees by the Parameters of the Tree-like Body : Effects of the Branching Angle and the Branching Length on Shape of Tree like Body, J.Theor. Biol., 31, 331-338, 1971

2) 本條毅：植物成長シミュレーションとコンピュータグラ フィックス, PIXEL109, 133-140, 1991

3）本條毅, 斎藤馨, 熊谷洋一：植物形状モデリングとその 可視化による景観予測に関する考察, 造園雑誌 55(5), 301-306，1992

4) R.Lecoustre : 私信, 1992

5）森本幸裕, 吉川賢, 李樹青, 小橋澄治：カイトセンシン グなどによる毛烏素砂漠の緑化状況モニタリング, 緑化 研究 10,217-226, 1988

6）森本幸裕, 吉田博宣, 小橋澄治：糺の森の樹木および土 壌調査 $(1)$, 緑化研究 6, 1984

7）森本幸裕：未発表

(1992. 11. 18受理) 